\title{
Pembinaan Olahraga Atletik bagi Siswa Cerebral Palsy Menuju Kejuaraan Paralympic Competition
}

\author{
Maidika Arta, Dimas Arif Dewantoro \\ Jurusan Pendidikan Luar Biasa, Universitas Negeri Malang \\ E-Mail: Maidikaarta@gmail.com
}

\begin{abstract}
ABSTRAK: Gerakan dasar atletik adalah gerakan dasar manusia di dalam kehidupannya sehari-hari, yaitu berjalan, berlari, melompat dan melempar. Pembinaan adalah proses dan usaha atau tindakan yang dilakukan untuk mengoptimalkan kemampuan siswa menjadi seorang atlet, salah satunya di cabang olahraga lari. Anak cerebral palsy mengalami gangguan di dalam otak, dan kelainan bersifat kekakuan pada anggota geraknya, sehingga anak cerebral palsy membutuhkan pembinaan dalam olahraga lari. Penelitian ini memiliki fokus adalah: (1) Program kegiatan pembinaan olahraga atletik bagi siswa cerebral palsy. (2) Teknik-teknik yang di ambil dalam sprint pada pembinaan olahraga atletik bagi siswa cerebral palsy (3) Pemenuhan kebutuhan gizi sebagai pendukung pembinaan olahraga atletik bagi siswa cerebral palsy. Penelitian ini menggunakan rancangan penelitian kualitatif dengan jenis penelitian studi kasus. Pengumpulan data yang dilakukan dengan wawancara, observasi, dan dokumentasi. Setelah data diperoleh kemudian data dianalisis dengan cara reduksi data, penyajian data dan penarikan kesimpulan. Kemudian mengecek keabsahannya dengan menggunakan: (1) Triangulasi pengecekan kembali informasi atau data yang sudah didapatkan atau sumber yang berbeda, (2) Menggunakan bahan referensi, (4) Mengadakan membercheck. Hasil penelitian ini meliputi: (1) Program pembinaan olahraga atletik bagi siswa cerebral palsy di SLB Pembina Tingkat Nasional Bagian C Malang. (2) Teknik-teknik yang diambil dalam sprintpada pembinaan olahraga atletik bagi siswa cerebral palsy menyesuaikan dengan kemampuan siswa, (3) Pemenuhan kebutuhan gizi sebagai faktor pendukung pembinaan olahraga atletik guna menjaga stamina tetap fit.
\end{abstract}

Kata Kunci: Pembinaan, Olahraga Atletik, Cerebral Palsy

\begin{abstract}
Athletic basic movement is the basic human movement in everyday life, ie walking, running, jumping and throwing. Coaching is the process and effort or action taken to optimize the ability of students to become an athlete, one of them in the sport of running. The child's cerebral palsy is disturbed in the brain, and the abnormality is stiffness in the limbs, so the cerebral palsy child needs coaching in the running sport. This research has focus are: (1) Program of athletic sports development activity for students of cerebral palsy. (2) Techniques taken in sprint on athletic sports coaching for students of cerebral palsy (3) Fulfill the nutritional needs as a supporter of athletic sports development for students of cerebral palsy. This research uses qualitative research design with case study research type. Data collection is done by interview, observation, and documentation. After data is obtained then the data is analyzed by data reduction, data presentation and conclusion. Then check the validity by using: (1) Triangulation re-checking information or data already obtained or different sources, (2) Using reference materials, (4) Conducting a membercheck. The results of this study include: (1) Athletic athletic coaching program for students of cerebral palsy in SLB Pembina Nasional Nasional Part C Malang. (2) Techniques taken in sprint on the development of athletic sports for students with cerebral palsy adjust to the students' ability, (3) Fulfill the nutritional needs as a support factor for athletic sports development in order to keep the stamina fit.
\end{abstract}

Key Words: Athletic Sports Development, Cerebral Palsy

Pembinaan olahraga atletik adalah suatu usaha dan tindakan yang digunakan dalam usaha secara berdaya guna untuk mencapai hasil yang baik.Untuk meningkatkan prestasi yang optimal perlu adanya SDM pengelolaan yang kompeten (Rumini 2015). Sudarsini (2013) mengatakan, olahraga atletik adalah gerakan yang dilakukan seseorang pada kehidupan sehari-hari, yaitu berjalan,berlari, melompat dan melempar. Siswa menghabiskan sebagian waktunya untuk bermain, melakukan kegiatan berlari, berjalan, melompat dan melempar. Olahraga atletik akan lebih di sukai siswa dikarenakan siswa sudah mengetahui sebelumnya gerakan dalam olahraga atletik, siswa akan lebih mudah memahami dan melakukan gerakan yang sudah diketahuinya sebagai gerakan atletik. Siswa perlu di bina dan dilatih bagaimana melakukan olahraga atletik dengan benar. Semua jarak lari mulai dari 100 sampai $400 \mathrm{~m}$ disebut sebagai sprint (Krempel, 1987).

Lari dapat dibedakan berdasarkan jaraknya yaitu sprint ,menengah dan jauh. Menurut Yoyo Bahagia, Ucup (2000) sprint yaitu lari menempuh jarak 100m, $20 \mathrm{~m}$ dan 400m. Sudarsini (2013) mengatakan sprint adalah gerakan lari yang maksimal mulai dari gerakan finish hingga start. Beberapa faktor dalam sprint ada tiga hal yaitu: a. start, b. sprint, dan c. gerakan finish. Kecepatan pada sprint adalah hasil yang dilakukan 
secara maksimal untuk mencapai finish.

Pembinaan olahraga atletik perlu ditingkatkan dan dioptimalkan sehingga terus melahirkan generasi muda yang berprestasi terutama bagi siswa berkebutuhan khusus "cerebral palsy". Sehingga dapat meraih kejuaran dalam event paralympic competition sehingga siswa lebih termotivasi. Memperoleh prestasi dan kejuaran dalam sebuah event, tentu tidak lepas dari latihan yang intensif dan rutin sehingga siswa dengan keterbatasan fisik mampu bersaing dan siap mental dalam perlombaan. Dengan kejuaraan ini atlet dapat meunjukan kemampuan dan prestasinya sejajar dengan atlet-atlet pada umunya yang tidak memiliki keterbatasan fisik atau berkebutuhan khusus. Dalam kompetisi paralympic ini dapat menunjukkan bibitbibit atlet yang memiliki bakat olahraga dan mampu bersaing sehingga dapat di kembangkan dan dibina secara lebih profesional. Siswa cerebral palsy sangat membutuhkan pembinaan olahraga atletik dikarenakan siswa cerebral palsy mengalami kekaukan otot, sehingga mengalami kelumpuhan anggota gerak bawah yang dapat mengakibatkan kemampuan untuk berguling, merangkak, duduk dan berjalan mengalami hambatan. Sementara kelumpuhan anggota gerak atas mengakibatkan kemampuan untuk meraih, menggenggam dan kemampuan lain yang berhubungan dengan fungsi tangan mengalami hambatan.

Musjafak (1995) mengatakan cerebral palsy menurut asal katanya terdiri atas dua kata Cerebral, , Celebrum yang berarti otak, dan Palsy berarti kekakuan. Menurut arti kata, Cerebral Palsy "kekakuan" disebabkan adanya kerusakan yang terletak didalam otak. Cerebral Palsy banyak pula dijumpai mengalami kelayuhan, gangguan gerak, gangguan koordinasi, getaran-getaran ritmis, dan gangguan sensoris. Cerebral Palsy tidak hanya bagian motorik saja yang mengalami kelainan tetapi juga pendengaran, penglihatan, kecerdasan dan kemampuan berbicara sehingga disebut kelainan kompleks. Cerebral palsy mengalami disfungsi sistem pada syaraf otak sehingga mengalami kelainan pada motoriknya (Abdullah, 2013). Kelainan fungsi akibat cerebral palsy salah satunya kelainan fungsi pada mobilisasi, kelainan fungsi mobilisasi dapat diakibatkan oleh adanya kekakuan anggota gerak tubuh, seperti tangan dan kaki. Cerebral Palsy adalah berbagai perubahan gerakan atau fungsi motor tidak normal dan timbul sebagai akibat kecelakaan, luka, atau penyakit susunan syaraf yang terdapat pada rongga tengkorak. Cerebral palsy dapat diartikan gangguan fungsi gerak yang diakibatkan oleh kecelakaan, luka, atau penyakit susunan syaraf yang terdapat pada rongga tengkorak (Pradipta, 2017)

Awalnya siswa kesulitan saat berjalan, tidak adanya keseimbangan sehingga saat berjalan ia sering mengalami kesulitan hingga terjatuh. Melihat cara berjalan siswa sering terjatuh, sehingga banyak guru yang meragukan kemampuan siswa dikarenakan kekakuan otot pada tangan dan kaki. Guru perbakatan atletik siswa ceberal palsy merasakan hal yang sama, yakni merasa ragu dan khawatir dengan kondisi yang dialami siswa. Semangat dan kemamuan siswa yang kuat yang menjadi faktor pendukung siswa dalam mengikuti pembinaan olahraga atletik sehingga siswa di latih keseimbangan berjalan agar siswa mampu mengikuti perlombaan atletik cabang lari, setelah adanya pembinaan atletik siswa mampu berjalan dengan benar secara bertahap dan sekarang dapat berlari, tentu saja banyak faktor pendung dalam keberhasilan olahraga atletik seperti program pembinaan, teknik yang digunakan, dan pemenuhan kebutuhan gizi siswa.

\section{METODE}

Penelitian ini dilakukan di SLB Pembina Tingkat Nasional Bagian C Malang tepatnya di Jl. Dr. Cipto VIII/32 Lawang. Kab Malang-Jawa Timur. Penelitian ini menggunakan pendekatan kualitatif dengan jenis penelitian studi kasus sehingga peneliti dapat mendiskripsikan dengan jelas dan rinci bagaimana pembinaan olahraga atletik bagi siswa cerebral palsy di SLB Pembina Tingkat Nasional Bagian C Malang. Kehadiran peneliti dalam penelitian sangatlah penting karena peneliti sebagai pengamat secara penuh tanpa terlibat langsung dalam proses pembinaan.

Sumber data dalam penelitian ini yaitu guru olahraga, guru kesiswaan/perbakatan, guru kurikulum (ahli Cerebral palsy). Pengamatan atau observasi dilakukan dengan cara mengamati proses pembinaan olahraga atletik serta pengambilan photo sebagai dokumentasi untuk memperkuat bukti wawancara maupun dokumentasi. Hasil wawancara dan hasil observasi ditulis dalam catatan lapangan serta menambahkan photo untuk memperkuat hasil dari observasi yang dilakukan.

Teknik pengumpulan data yang di gunakan dalam penelitian kualitatif, yaitu observasi, observasi yang digunakan adalah observasi partisipatif yaitu observasi pasif, peneliti hanya mengamati bagaimana kegiatan yang sedang berlangsung tetapi tidak ikut terlibat di dalam proses di sedang dilaksanakan; wawancara yang digunakan dalam penelitian ini yaitu wawancara tidak berstruktur, yaitu wawancara yang bebas dengan menggunakan pedoman wawancara secara garis besar yang memebahas fokus dalam penelitian; dokumentasi yaitu menghimpun dokumen-dokumen yang sesuai dengan fokus penelitian.

Langkah-langkah dalam menganalisis data yang dilakukan dalam penelitian ini yaitu: (1) mereduksi data atau peneyederhanaan data, dengan pemilihan data yang di dapat dari hasil observasi, wawanccara, dan dokumentasi; (2) paparan atau sajian data, dengan menyatukan berbagai informasi yang sudah di dapat dari setiap fokus penelitian kemudian membuat kesimpulan sementara; (3) penarikan kesimpulan, dengan menganalisis data terus menerus ada saat 
penelitit berada di lapangan pada saat pengumpulan data juga pada saat penyajian data. Selanjutnya pengujian kredibilitas antara lain dilakukan dengan triangulasi, kecukupan bahan referensi, dan mengadakan membercheck.

\section{HASIL DAN PEMBAHASAN}

\section{Hasil}

Berdasarkan hasil penelitian, pembinaan olahraga atletik bagi siswa cerebral palsy sudah lama ada di SLB Pembina Tingkat Nasional Bagian C Malang tetapi tidak terprogram dan kurang efektif pelaksanaanya. Pembinaan olahraga atletik awalnya rutin dilaksanakan tiga bulan sebelum event.

Pembinaan olahraga atletik pada cabang lari ini menggunakan teknik latihan $\mathrm{ABC}$ running, pada dasarnya siswa cerebral palsy mampu mengikuti setiap teknik yang diberikan, hanya saja siswa tidak dapat semaksimal anak pada umunya dikarenakan kekakuan otot yang di alami siswa Cerebral palsy. Pembinaan olahraga atletik bagi siswa Cerebral palsy di dukung dengan pemenuhan kebutuhan siswa dengan memberi susu, puding telur, roti, madu, dan kacang hijau guna membantu gizi seimbang siswa Cerebral palsy dalam mengikuti pembinaan olahraga atletik.

\section{Pembahasan}

Sudarsini (2016) mengatakan Cerebral palsy adalah istilah kedokteran yang mengacu pada salah satu kekacauan gerak disebabkan cara kerja otak yang tidak baik dan juga mengacu pada kelumpuhan otak (brain paralysis). Cerebral palsy dikenal sejak tahun 1957 oleh Dr. Wintrop Phelp. Ia mengatakan bahwa CP merupakan suatu kelainan pada gerak tubuh yang ada hubungannya dengan kerusakan otak yang menetap.

Gangguan koordinasi terjadi pada anak Cerebral palsy berkaitan dengan tidak adanya kerjasama yang harmonis antar anggota tubuh yang dimiliki, seperti mata dengan tangan. Gangguan psikologis terjadi kemungkinan secara primer karena menyangkut pusat-pusat psikologis yang terletak di dalam otak atau mungkin karena proses penyesuaian diri dan perkembangan pribadi yang tidak dapat berkembang sebagai layaknya karena sikap yang tidak menunjang dari lingkungan. Kelainan sensoris sering kali dijumpai pada anak-anak cerebral palsy sebagai bentuk kelainan penyerta dan tidak semua anak cerebral palsy mengalami gangguan sesnsoris. Hal ini dipengaruhi oleh ada tidaknya gangguan dalam otak yang berhubungan dengan fungsi sensoris "indera" (Musjafak, 1995). Penyandang kelainan cerebral palsy, memiliki kerusakan pada sistemsyaraf pusatnya. Fungsi yang penting dan terkena gangguan dikarenakan kerusakan pada otak, seperti sumsum tulang belakang berfungsi sebagai menyampaikan pesan dan bagian anggota tubuh lainnya. Menyampaikan pesan berupa perintah seperti mengambil buku, dan menutup pintu. Otak juga berfungsi menerima ransangan balik dari luar melalui saluran sumsum tulang belakang, dan otak menilai balikan tersebut. Rangsangan dari luar, misalnya perintah mengambil buku Bahasa Indonesia, atau informasi tentang dirinya yaitu "kukumu sudah panjang", pesan itu tidak dimengertinya. Atau pesan itu diterima, tetapi salah menginterpretasikan. Seperti mengambil pensil di atas meja, pensil tidak dapat diambil walaupun ia telah melakukan dengan susah payah dikarenakan tidak adanya kerja sama antara mata dengan tangannya (Musjafak 199). Dalam Undang-undang Nomor 3 Tahun 2005 Tentang Sistem Keolahragaan Nasional Pasal 25 ayat 6 menyebutkan untuk menumbuh kembangkan prestasi olahraga di lembaga pendidikan, pada setiap jalur pendidikan dapat dibentuk unit kegiatan olahraga, kelas olahraga, pusat pembinaan dan pelatihan, sekolah olahraga, serta diselenggarakannya kompetisi olahraga yang berjenjang dan berkelanjutan. Undang-undang Nomor 3 Tahun 2005 Tentang Sistem Keolahragaan Nasional Pasal 25 ayat 3 juga menyebutkan bahwa pembinaan dan pengembangan olahraga pendidikan pada semua jenjang pendidikan memberikan kebebasan kepada peserta didik untuk melakukan kegiatan olahraga sesuai bakat dan minat. Program pembinaan olahraga atletik bagi siswa cerebral palsy adalah sebagai proses pembentukan siswa Cerebral palsy agak menjadi atlet yang dapat bersaing dalam kegiatan olahraga lari. Dengan adanya program pembinaan maka pembinaan rutin dapat dilakukan secara efektif, kegiatan dilakukan secara berdaya guna dan berhasil guna dengan baik, sehingga dapat mencapai hasil yang optimal.

Krempel (1987) menyatakan bahwa semua kegiatan latihan pada hakikatnya ditujukan untuk mencapai kondisi tertinggi yang direncanakan serta prestasi puncak dalam perlombaan cabang olahraga yang bersangkutan. Sehingga perlu adanya program dalam rangka perencanaan latihan dan perlombaan menjadi suatu keharusan. Program pembinaan olahraga atletik dilaksanakan pada jam 06:15-07:15 sebelum memasuki jam pelajaran di sekolah. Peembinaan olahraga atletik yang di laksanakan pada pagi hari sebelum memasuki jam pelajaran yaitu pembinaan olahraga lari,sebelum memulai pembinaan para siswa atlet lari yang beranggotakan siswa cerebral palsy, larilari kecil memutari sekolah hingga tiga kali putaran dan kemudian peregangan, para atlet diajarkan teknik start, teknik saat berlari hingga teknik saat finish kemudian latihan fisik dengan menggunakan teknik ABC Running.

Teknik-teknik yang pada pembinaan olahraga atletik bagi siswa Cerebral palsy, pada umunya sama seperti siswa reguler hanya saja ada beberapa gerakan pada teknik spint tidak dapat di lakukan oleh siswa Cerebral palsy dengan maksimal seperti siswa pada 
umumnya. Power adalah kemampuan kerja otot, karena kekuatan atau power yang di miliki atlet berbanding lurus dengan kekuatan otot sehingga besar kecilnya kekuatan atau power di tentukan dengan kekuatan otot (Tjaliek Soegiardo, 1992).

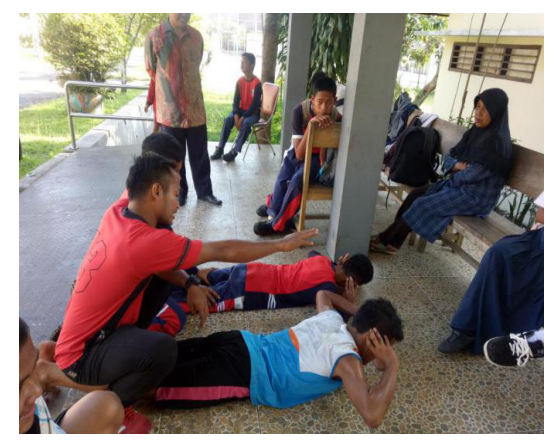

Gambar 1. Siswa melakukan latihan kekuatan otot

Pada pembinaan olahraga atletik di SLB Pembina Tingkat Nasional Bagian C Malang menggunakan teknik variasi $\mathrm{ABC}$ running sama seperti olahraga lari pada umunya, siswa dapat melakukan semuaa gerakan pada teknik ABC running, tetapi ada beberapa gerakan yang dilakukan tidak maksimal dikarenakan kekakuan pada otot tangan dan kakinya. Teknik gerakan tungkai (ABC Running a dan b): siswa dapat melakuk gerakan tungkai dengan baik. Teknik gerakan lutut (ABC Running c): siswa kesulitan melakukan gerakan running c dikarenakan kekakuan pada kaki kanannya. Teknik gerakan tangan: siswa dapat melakukan gerakan tangan tetapi tidak maksimal, dikarenakan kekakuan pada otot tangan kanannya. Teknik gerakan bungungan tiungkai: siswa dapat melakukan gerakan bungungan tungkai tetapi tidak maksimal.

Sudarsini (2013) mengatakan bahwa lari jarak pendek (print) adalah semua jenis lari yang sejak dari start sampai finish dilakukan dengan kecepatan maksimal sesuai dengan kemampuan atlet. Gerakan pada start, gerakan sprint, gerakan finish adalah faktor yang mutlak menentukan baik buruknya dalam sprint. Pada teknik ini siswa hanya melakukan gerakan sprint saja dan kurang memaksimalkan gerakan start dan finish.

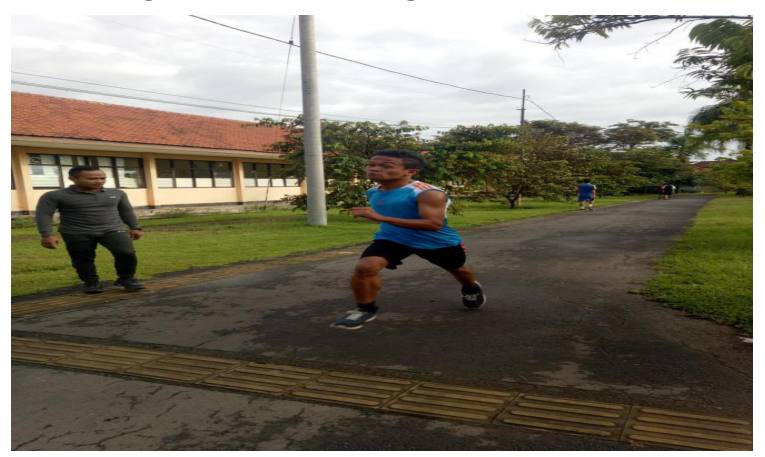

Gambar 2. Siswa melakukan gerakan sprint di bina olah guru olahraga
Gerakan yang sering dilupakan dalam teknik ini yaitu gerakan start dan finish (a) gerakan start: dalam gerakan ini siswa cerebral palsy tidak melakukan sesuai intruksi pelatih yaitu setelah hitungan ke tiga, adanya tekanan dan kecepatan saat mulai melakukan gerakan sprint. Sehingga atlet mengalami penambahan waktu saat harus menuju ke finish. (b) gerakan sprint: dikarenakan atlet lari pada pembinaan ini siswa cerebral palsy maka kesulitan yang dialami saat berlari yaitu tekanan pada kaki kiri, karena tumpuan kaki kanan selalu lebih pendek.

Siswa cerebral palsy saat melakukan gerakan sprint selalu condong kekanan sehingga saat menuju garis finish atlet berada terlalu jauh ke kanan. Kekakuan yang dialami atlet cerebral palsy menjadikan gerakan tangan kaku sehingga tidak dapat selaras antara tangan dan gerakan kaki, untuk kecepatan gerakan sprint menempuh waktu 14-17 detik tidak terlalu jauh berbeda dengan siswa pada umunya. (c) gerakan finish: saat melakukan gerakan finish, sering melaupakan tekanan melompat saat sampai ke finish. Pada awalnya siswa cerebral palsy tidak dapat berlari, untuk berjalan saja mengalami kesulitan tetapi dengan adanya pembinaan olahraga atletik membantu atlet cerebral palsy dalam melakukan sprint sehingga dapat bersaing saat pertandingan.

Asmuni (1979) menyatakan bahwa, badan yang sehat adalah hasil interaksi berbagai faktor yang mempengaruhi kondisi tubuh manusia yang bersangkutan, baik langsung maupun tidak langsung. Pemilihan makanan dan dan gizi yang tepat dan seimbang bagi olahragawan dapat membantu bahkan di perlukan dalam usahanya mengejar prestasi. Saham gizi yang tepat dan seimbang ini bagi seorang olahragawan akan dapat mempertahankan berat badan seperti yang diinginkan (desirable weight), kesempurnaan- physical fitness dan perkembangan refleks otot-syaraf yang sangat dibutuhkan itu.

Nutrisiyang cukup bagi para atletik bertujuan agar atletik memiliki kecukupan gizi yang optimal. Oksigen, air dan zat gizi dibutuhkan untuk proses kehidupan. Makanan yang di dikonsumsi oleh seorang atlet harus memenuhi semua zat gizi yang dibutuhkan untuk mengganti zat-zat gizi dalam tubuh yang berkurang akibat digunakan untuk aktivitas sehari-hari dan olahraga. Menu seorang atlet harus mengandung semua zat gizi yang diperlukan yaitu karbohidrat, lemak, protein, vitamin, mineral dan air. Menu ini disusun berdasarkan jumlah kebutuhan energi dan komposisi nutrien penghasil energi yang seimbang (Arsani, N. L. K. A. 2014). Gizi mendukung performa atlet saat melakukan pembinaan. Gizi mampu menjaga kebugaran dengan baik dan optimal. Gizi yang baik akan membuat energi pada pembinaan olahraga atletik. Pemenuhan zat gizi untuk atlet yaitu karbohidrat, protein, lemak, vitamin, dan mineral serta air menjadi perhatian penting dan utama sebagai kebutuhan gizi. Dalam memenuhi kebutuhan gizi maka kita harus 
menyesuaikan antara asupan gizi dan gizi yang keluar sehingga terjadi keseimbangan energi para atlet.

Sedangkan protein adalah zat pembangun penting, sebab setelah melakukan pembinaan seperti bertanding maka atlet akan mengalami kerusakan otot sehingga terjadi cidera apabila tidak segera mendapatkan zat gizi sebagai proses pemulihan setelah melakukan pertandingan. Asupan lain yang dibutuhkan yakni lemak sebagai sumber penghantar vitamin yang baik di dalam tubuh. Tetapi lemak bukanlah yang utama, sehingga penting peran lemak agar tidak berlebihan dan memicu terjadinya penumpukkan lemak yang dapat menggangu performa atlet.

Asupan memiliki peran penting adalah air. Bagian tubuh 65 persen adalah cairan, sehingga cairan sangatlah pentin. Kebutuhan gizi atlet sangatlah harus di perhatikan, bukan hanya atlet tetapi juga menjadi perhatian pelatihnya, agar kondisiatlet tetap terjaga. Pemilihan makanan dan gizi seimbang bagi olahragawan karena dapat membantu bahkan diperlukan dalam usahanya mengejar prestasi puncak (Asmuni, 1979:45).

Pemenuhan kebutuhan gizi yang seimbang akan membantu siswa dalam mencapai prestasinya, di SLB Pembina Tingkat Nasional Bagian C Malang sangat memperhatikan pemenuhan kebutuhan gizi para siswa yang mengikuti pembinaan olahraga atletik terutama siswa Cerebral palsy. Setiap hari setelah melakukan pembinaan olahraga atletik setiap siswa diberi asupan gizi berupa roti, susu, dan telur sebagai kebutuhan gizi para siswa atletik. Kebutuhan gizi di berikan setelah pembinaan di laksanakan. Pemenuhan gizi memberi roti, puding telur, susu sapi, madu, buah dan kacang hijau. Pemenuhan gizi ini rutin setelah melakukan pembinaan olahraga agar anak terpenuhi kebutuhan gizinya.

\section{KESIMPULAN DAN SARAN}

\section{Kesimpulan}

Program kegiatan pembinaan olahraga atletik di SLB Pembina Tingkat Nasional Bagian C Malang merupakan program yang sudah ada di sekolah, hanya saja program ini rutin di laksanakan jika adanya event. Untuk persiapan menjelang event setiap peserta wajib mengikuti pembinaan 3 bulan sebelum event di gelar. Saat ini program kegiatan pembinaan olahraga atletik sudah rutin dilaksanakan setiap hari selasa dan kamis pada pukul 06:15 hingga 07:25, siswa melaksanakan kegiatan pembinaan dengan datang ke sekolah kemudian lari memutari sekolah selama 3 kali kemudian berlatih start dan kekuatan otot.

Teknik pembinaan olahraga atletik bagi siswa cerebral palsy sama seperti tehnik lari yang di gunakan pada umumnya yaitu menggunakan tehnik ABC Running, hanya saja beberapa gerakan tidak dapat dilakukan secara efektif di karenakan kekakuan otot yang dialami siswa cerebral palsy.

Dalam pemenuhan kebutuhan gizi Susu merupakan salah satu bahan pangan yang sangat penting bagi pemenuhan kebutuhan gizi masyarakat. Susu berperan sebagai asupan penting untuk kesehatan, kecerdasan, dan pertumbuhan, khususnya anak-anak, tidak hanya atletik siswa pada umumnya juga memebutuhkan susu sebagai kebutuhan gizi (Farid, M., \& Sukesi, H. 2011). Pemenuhan kebutuhan gizi dengan memberikan susu, roti, madu, kacang hijau dan telur sebagai puding kepada para siswa yang telah selesai melaksanakan pembinaan olahraga atletik.

\section{Saran}

Pembinaan olahraga atletik di SLB Pembina Tingkat Nasional Bagian C Malang sangat bagus dan dapat meningkatkan kemampuan siswa dalam mempersiapkan diri menuju paralympic competition, sehingga perlu adanya tambahan hari dan waktu agar pembinaan lebih efektif, tidak semua sekolah memiliki program pembinaan olahraga atletik khususnya cerebral palsy sehingga perlu adanya peningkatan agar pembinaan olahraga atletik tetap efektif. Berdasarkan hasil temuan peneliti diharapkan penelitian ini dapat menjadi bahan rujukan dalam penelitian selanjutnya tentang pembinaan olahraga atletik, dengan menggali informasi yang lengkap dan akurat mengenai program kegiatan harian yang dapat mengukur peningkatan kemampuan siswa cerebral palsy dan terus menggali informasi yang dapat meningkatkan kemampuan siswa cerebral palsy. Mengadakan perbandingan dengan siswa cerebral palsy berprestasi lainnya agar mendapatkan perbandingan dan dapat dijadikan rujukan. Menggunakan bahan referensi yang cukup agar mendapatkan informasi yang lebih akurat.

\section{DAFTAR RUJUKAN}

Abdullah, N. (2013). Mengenal anak berkebutuhan khusus. Magistra, 25(86), 1.

Arsani, N. L. K. A. (2014). Manajemen Gizi Atlet Cabang Olahraga Unggulan di Kabupaten Buleleng. JST (Jurnal Sains dan Teknologi), 3(1).

Efendi, M. (2006). Pengantar Psikopedagogik Anak Berkelainan. Jakarta: Bumi Aksara.

Farid, M., \& Sukesi, H. (2011)Pengembangan susu segar dalam negeri untuk pemenuhan kebutuhan susu nasional. Buletin Ilmiah Litbang Perdagangan, 5(2), 196-221.

Ika Dwi, L. (2012). HUBUNGAN ANTARA POWER OTOT TUNGKAIDENGAN KEMAMPUAN LARI JARAK PENDEK (SPRINT) 100 METER SISWA SMK N 1 KLATEN JURUSAN AKUNTANSI (Doctoral dissertation, UNIVERSITAS NEGERI 
YOGYAKARTA).

Krempel. R. (1987). Atletik. Jakarta: Rosya Jaya Putra. Musjafak. A (1995). Ortopedagogik Anak Tuna Daksa. Bandung: ProyekPendidikan Tenaga Guru.

Pradipta, R. F., \& Andajani, S. J. (2017). Motion Development Program for Parents of Child with Cerebral Palsy. Jurnal Penelitian dan Pengembangan Pendidikan Luar Biasa, 4(2).

Rumini, R. (2015). MANAJEMEN PEMBINAAN CABANG OLAHRAGA ATLETIK DI PUSAT PENDIDIKAN DAN LATIHAN PELAJAR (PPLP) PROVINSI JAWA TENGAH. Journal of Physical Education Health and Sport, 2(1), 20-27.
Sudarsini. (2013). Pendidikan Jasmani Dan Olahraga. Malang: Fakultas Ilmu Pendidikan Universitas Negeri Malang.

Sudarsini. (2016). Pendidikan Jasmani Adaptif. Malang: Gunung Samudera.

Sugiyono. (2014). Metode Penelitian Kuantitatif, Kualitatif Dan R\&D. Bandung: Alfabeta, CV.

Undang-undang Republik Indonesia Nomor 3 Tahun 2005. 2006. Sistem Keolahragaan Nasional. Yogyakarta: Pustaka Yustisia. 